\title{
Strategi Peningkatan Target Wajib Pajak Bagi UMKM Dengan Metode Analytic Network Process (ANP)
}

\author{
Imelda Dian Rahmawati ${ }^{1}$, Muhammad Nasih ${ }^{2}$ \\ ${ }^{1}$ Fakultas Bisnis, Hukum dan IImu Sosial, Universitas Muhammadiyah Sidoarjo, ${ }^{2}$ Fakultas Ekonomi dan Bisnis, Universitas \\ Airlangga Surabaya
}

The development of MSME in Indonesia is very rapid, but this development is not supported by tax compliance. This requires a strategy that needs to be designed by DGT so that this potential can be optimized. The purpose of this study was to determine strategies for increasing tax revenues from the micro small and medium business sector (MSMEs) with the Network Process Analysis (ANP) method. This type of research is field study research. Data sources used in this study are primary and secondary data sources. Data collection techniques in this study used observation, interview, documentation, questionnaire, and literature study techniques. Data analysis techniques in this study used the ANP method. The results of this study, among others, based on the NetworkProcess Analysis (ANP) method, obtained priority strategies for increasing revenue from the MSME sector with the Network Process Analysis (ANP) method. The first rank that gets the highest value is the strategy to increase tax services to MSME taxpayers. Tax services to MSME taxpayers include ease in tax reporting, ease in tax payments, and ease in accessing tax information.

Keywords: MSMEs Tax Revenue Improvement, ANP, Tax Services, Tax Compliance

OPEN ACCESS ISSN 2528-4649 (online) ISSN 2338-4409 (print)

${ }^{*}$ Correspondence:

Received: 10 Desember 2019 Accepted: 25 Februari 2020 Published: 4 Maret 2020

Citation:

Rahmawati ID and Nasih M (2020) Strategi Peningkatan Target Wajib Pajak Bagi UMKM Dengan Metode Analytic Network Process (ANP). STRATEGI PENINGKATAN TARGET

WAJIB PAJAK BAGI UMKM

DENGAN METODE ANALYTIC NETWORK PROCESS (ANP). 6:1. doi: http://doi.org/10.21070/jbmp.v

$6 i 1.439$
Perkembangan UMKM di Indonesia sangat pesat, tetapi perkembangan ini tidak didukung dengan kepatuhan pajak. Hal tersebut diperlukan strategi yang perlu dirancang oleh DJP agar potensi tersebut bisa optimal. Tujuan penelitian ini adalah untuk mengetahui strategi peningkatan penerimaan pajak dari sektor usaha mikro kecil dan menengah (UMKM) dengan metode Analisis Network Process (ANP). Jenis Penelitian ini penelitian studi lapangan. Sumber data yang digunakan dalam penelitian ini adalah sumber data primer dan sekunder. Teknik pengumpulan data pada penelitian ini menggunakan teknik observasi, wawancara, dokumentasi, kuisioner, dan studi pustaka. Teknik analisis data pada penelitian ini menggunakan metode ANP. Hasil penelitian ini antara lain berdasarkan metode Analisis NetworkProcess (ANP) didapatkan prioritas strategi peningkatan penerimaan pada dari sektor UMKM dengan metode Analisis Network Proses (ANP). Rangking pertama yang mendapatkan nilai tertinggi yaitu strategi peningkatan pelayanan pajak kepada wajib pajak UMKM. Pelayanan pajak kepada wajib pajak UMKM ini meliputi kemudahan dalam pelaporan pajak, kemudahan dalam pembayaran pajak, dan kemudahan dalam mengakses informasi pajak.

\footnotetext{
Keywords: MSMEs Tax Revenue Improvement, ANP, Tax Services, Tax Compliance
} 


\section{PENDAHULUAN}

Pajak merupakan sebuah hal yang penting dalam sebuah Negara karena di dalam pelaksanaan pembangunan, pajak merupakan sumber dalam anggaran negara dari pendapatan. Meskipun pajak merupakan sumber pendapatan bagi anggaran negara, namun dalam pelaksanaannya penerimaan pajak belum mencapai target yang diinginkan. Data realisasi penerimaan pajak menunjukkan bahwa total penerimaan pajak hingga 31 agustus 2015 sebesar 598.270 triliun rupiah menurun sebesar 1,07\% dan penerimaan pajak periode yang sama di tahun 2014, padahal target penerimaan pajak ditahun 2015 lebih tinggi 31\% dibandingkan dengan realisasi penerimaan pajak di tahun 2014 (Annisa,2017).

Sektor usaha mikro, kecil, dan menengah (UMKM) berperan sangat besar dalam struktur pereknomian Indonesia. Menurut data Kementerian Koperasi dan UMKM (2009), diperkirakan sekitar Rp 1.214,73 triliun atau 58,17\% dari total produk domestic bruto (PDB) berasal dari sektor ini. Menurut catatan Direktorat Jenderal Pajak (Ditjen) Pajak, sumbangan penerimaan pajak sektor ini hanya Rp 65,012 miliar atau baru mencapai 0,54\% dari total PDB sektor UMKM. Angka statistik tersebut mengindikasikan masih banyaknya potensi pajak dari sektor UMKM yang belum digali secara maskimal. Wajib pajak UMKM memiliki tingkat kepatuhan yang lebih rendah jika dibandingkan dengan wajib pajak badan maupun wajib pajak orang pribadi (dalam hal ini karyawan). Menurut (Annisa, 2017), terdapat beberapa faktor yang menyebabkan rendahnya kepatuhan pajak dari pelaku UMKM, diantaranya :

1. Usaha rumah tangga merupakan pelaku utama yang mendominasi pada sektor UMKM. Berdasarkan fakta dilapangan, peran sektor UMKM pada kelompok ini tidak memperdulikan dengan permasalahan ketentuan yang telah berlaku pada Peraturan Pemerintah (PP) Nomor 46 Tahun 2013 tentang Pajak Penghasilan dari usaha yang diterima Atau yang diperoleh Wajib Pajak yang memiliki peredaran bruto tertentu.

2. Para pelaku UMKM berasal dari orang pribadi yang memiliki badan usaha perorangan (self imployment). Jenis pelaku usaha ini mempunyai karakteristik cenderung kurang patuh dibandingkan karyawan, dimana atas pemotongan pajak dilakukan ketika penghasilan atau upah dibayarkan kepada karyawan (witholding). Pelaporan seluruh hasil kegiatan usaha orang pribadi swa-usaha dikemas dalam bentuk SPT. Tetapi, banyak pelaku UMKM yang belum mengetahui tentang perpajakan membuat mereka tergabung dalam kelompok tidak patuh terhadap pajak.

Pelaku UMKM biasa bergerak di sektor informal, sehingga catatan seorang wajib pajak UMKM dan tidak adanya relatif transaksi yang telah dilakukannya. Karena hal tersebut administrasi pajak kesulitan dalam mengawasi kepatuhan pelaku wajib pajak UMKM. Karena pergerakan yang terjadi pada sektor informal, membuat kesadaran pelaku pajak UMKM untuk berkontribusi untuk penyediaan barang dan jasa publik yang berdampak pada kerendahan kepatuhan pajak.

Analytic Network Process atau ANP adalah pengambilan keputusan secara sistematik ketika menghadapi faktor yang saling berhubungan (dependance) dan umpan balik (feedback) dengan menggunakan teori matematis. ANP merupakan suatu metode yang digunakan dalam mengambil keputusan dengan menggunakan dasar dari beberapa kriteria atau Multiple Criteria Decision Making (MCDM) yang dikembangkan oleh Thomas L. Konsep ANP dikembangkan dari teori AHP yang didasarkan dari hubungan saling ketergantungan antara beberapa komponen, sehingga AHP merupakan bentuk khusus dalam ANP. ANP dapat digunakan sebagai salah satu penurunan rasio prioritas komposit yang bersumber dari skala rasio individu yang saling berinteraksi dengan kriteria kontrol dan mencerminkan pengukuran relatif dari pengaruh elemen yang berkenaan. Proses pengambilan keputusan menggunakan metode ANP dengan memperlakukan keputusan tanpa membuat asumsi-asumsi tentang independensi elemen dari elemen yang lebih tinggi ke elemen yang lebih rendah dan tentang elemen independensi elemen pada suatu level (Ascarya,2005). 


\section{TUJUAN PENELITIAN}

Berdasarkan dari beberapa pembahasan permasalah tersebut diatas maka, tujuan dari penelitian ini adalah sebagai berikut : "Untuk mengetahui strategi peningkatan penerimaan pajak dari sektor usaha mikro kecil dan menengah (UMKM) dengan metode Analisis Network Process (ANP).

\section{KERANGKA PENELITIAN}

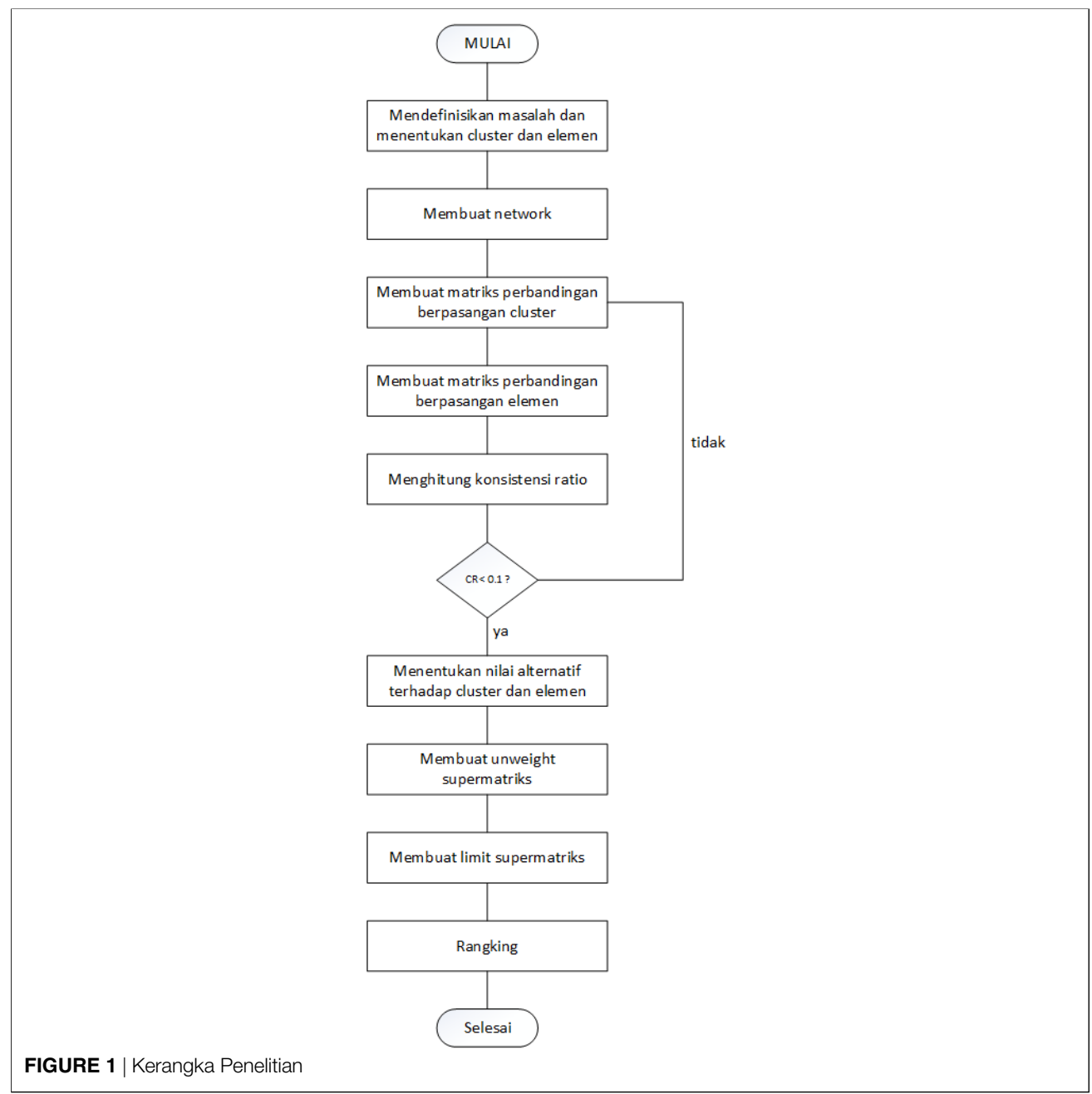

\section{METODE PENELITIAN}

Penelitian ini dengan pendekatan kualitatif deskriptif. Metode kualitatif deskriptif digunakan untuk membangun sebuah analisa yang kongkrit pada penerapan strategi Direktorat Jenderal Pajak (DJP) dan bagaimana Stetegi tersebut dapat meningkatkan penerimaan pajak dari sektor usaha mikro kecil dan menengah (UMKM). Metode kualitatif akan mengidentifikasi adanya faktor-faktor yang digunakan untuk landasan dalam pengambilan keputusan jangka panjang mengenai stretegi peningkatan penerimaan pajak dari sektor usaha mikro kecil dan menengah (UMKM). 


\section{Fokus Penelitian}

Fokus penelitian ini adalah menganalisis strategi yang telah digunakan oleh Direktorat Jenderal Pajak (DJP) dalam rangka meningkatkan penerimaan pajak dari sektor UMKM dengan menggunakan metode Analysis Network Process (ANP).

\section{Lokasi Penelitian}

Lokasi penelitian ini dilakukan di kantor pelayanan pajak KPP Pratama Sidoarjo Utara, KPP Pratama Sidoarjo Barat, KPP Pratama Sidoarjo Selatan.

\section{Landasan ANP}

ANP memiliki empat aksioma yang menjadi landasan teori, antara lain:

1. Respirokal, aksioma ini menyatakan bahwa jika PC (EA, EB) adalah nilai perbandingan pasangan dari elemen $\mathrm{A}$ dan $\mathrm{B}$, dilihat dari elemen induknya $\mathrm{C}$, yang menunjukkan berapa kali lebih banyak elemen induknya $\mathrm{C}$, yang menunjukkan berapa kali lebih banyak elemen A memiliki apa yang dimiliki elemen B, maka PC (EB, EA)=1/Pc (EA, EB). Misalkan jika A lima kali lebih besar dari B,

2. Homogenitias, menyatakan bahwa elemen-elemen yang dibandingkan dalam struktur kerangka ANP sebaiknya tidak memiliki perbedaan terlalu besar, yang dapat menyebabkan lebih besarnya kesalahan dalam menentukan penilaian elemen pendukung yang mempengaruhi keputusan.

3. Prioritas, yaitu pembobotan secara absolut dengan menggunakan skala interval $(0,1)$ dan ukuran dominasi relatif.

4. Dependence condition, diasumsikan bahwa susunan dapatdikomposisikan ke dalam komponen-komponen yang membentukbagian berupa cluster.

TABLE 1 | Definisi Skala Penilaian dan Skala Numerik

\begin{tabular}{ll}
\hline Definition & Intencity of Importance \\
Extreme Importance & 9 \\
For Compromises Between the Above Values & 8 \\
Very Strong and Demonstrated Importance & 7 \\
For Compromises Between the Above Values & 6 \\
Strong Importance & 5 \\
For Compromises Between the Above Values & 4 \\
Moderate Importance & 3 \\
For Compromises Between the Above Values & 2 \\
Equal Importance & 1 \\
\hline
\end{tabular}

\section{Prinsip Dasar ANP}

Prinsip-prinsip dasar ANP terdiri dari tiga prinsip, yaitu dekomposisi, penilaian komparasi dan komposisi hierarki atau sintesis dari prioritas (Fielnanda, $2016: 29$ )

- Prinsip dekomposisi, diterapkan untuk menstrukturkan masalah yang kompleks menjadi kerangka hierarki atau jaringan cluster, sub-cluster, sub-sub cluster dan seterusnya. Dengan kata lain dekomposisi adalah memodelkan masalah ke dalam kerangka ANP.

- Prinsip penilaian komparasi, diterapkan untuk membangun perbandingan pasangan (pairwise comparison) dari semua kombinasi elemen-elemen dalam cluster dilihat dari cluster induknya. Perbandingan pasangan ini digunakan untuk mendapatkan prioritas lokal dari elemen-elemen dalam suatu cluster dilihat dari cluster induknya.

- Prinsip komposisi hierarki atau sintesis, diterapkan untu mengalikan prioritas lokal dari elemen-elemen dalam cluster 


\section{Langkah langkah dalam ANP}

1. Membuat suatu hirarki jaringan keputusan yang menunjukkan hubungan antar factor keputusan

2. Membuat matriks perbandingan berpasangan diantara faktor yang mempengaruhi keputusan

Matriks perbandingan berpasangan ini dibutuhkan untuk menghitung dampaknya pada alternatif-alternatif yang saling dibandingkan dengan skala rasio pengukuran 1-9 (tabel 1) yang dikembangkan oleh Saaty.

\section{Informan}

Informan dalam penilitian ini adalah karyawan kantor pajak Sidoarjo dari 3 KPP yang ada di Sidoarjo. Dengan perwakilan 25 karyawan per KPP yang ada di Sidoarjo, sehingga responden berjumlah 75 orang.

\section{Analisis Data}

- Mendefinisikan masalah serta menentukan cluster dan elemen (subkriteria)

Langkah pertama dalam metode ANP ialah mencari tahu tujuan dari masalah. Dalam kasus ini, masalah yang akan diselesaikan serta tujuan yang diharapkan akan tercapai ialah menetapkan startegi dari beberapa alternatif strategi.

Kriteria-kriteria yang akan dinilai ialah kriteria yang sudah dilakukan oleh Direktorat Jenderal Pajak tentang Peningkatan Penerimaan Pajak Sektor UMKM. Kriteria pada kasus ini bisa disebut juga dengan cluster dalam metode ANP. Ada 3 (tiga) cluster dalam kasus ini, di antaranya Daya Dukung, SDM, serta Alternatif strategi. Tiap cluster mempunyai elemen atau subkriteria yang bisa dilihat pada gambar 2 .

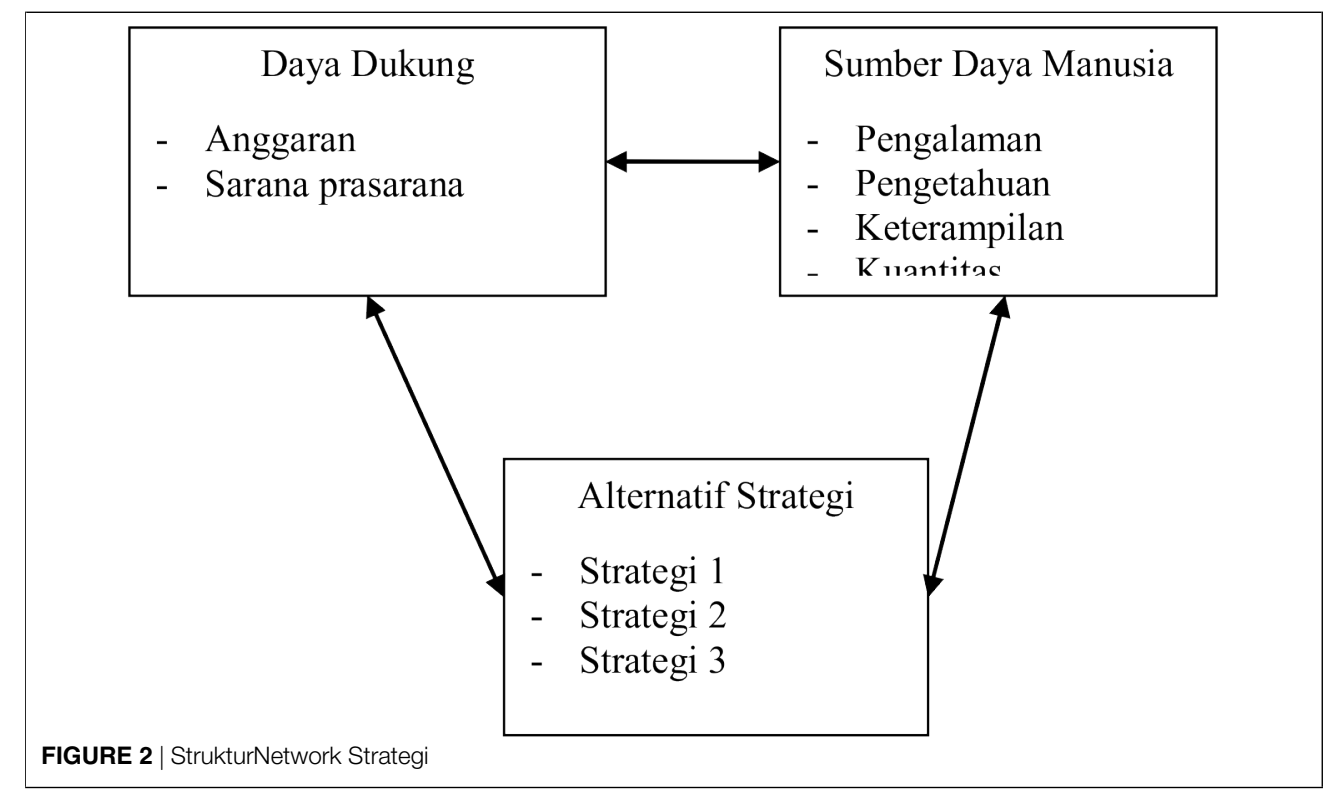

- Membuat matriks perbandingan berpasangan cluster

Matriks komparasi/ perbandingan cluster memakai skala intensitas kepentingan AHP dengan memperhatikan hubungan pengaruh atau kergantungan antar $c l u s t e r$. Fungsi dari matriks komparasi berpasangan ini ialah guna memperoleh nilai eigen serta melihat konsistensi rasio perbandingan $(\mathrm{CR})$, dengan syarat $\mathrm{CR} \leq 0.1$. Nilai perbandingan ini didapat dari pengambil keputusan. 
TABLE 2 | Perbandingan Tingkat Kepentingan Cluster Terhadap SDM

\begin{tabular}{lll}
\hline Cluster & & Nilai Kepentingan \\
Daya Dukung & Sumber Daya Manusia & sangat lebih penting \\
Daya Dukung & Alternatif Strategi & Sangat lebih penting \\
Sumber Daya Manusia & Alternatif Strategi & sedikit lebih penting \\
\hline
\end{tabular}

\section{HASIL DAN PEMBAHASAN}

\section{Elemen yang Berpengaruh Terhadap Strategi Peningkatan Penerimaan Pajak Sektor UMKM}

Elemen untuk mendukung strategi peningkatan penerimaan pajak sektor UMKM adalah Daya dukung dan sumber daya manusia. Daya dukukung memiliki beberapa sub kriteria atau sub elemen anggaran dan sarana prasarana sedangan sumber daya manusia terdiri atas sub kriteria atau elemen pengalaman, pengetahuan, keterampilan, dan kuantitas.

Peranan anggaran pada suatu organisasi merupakan alat untuk membantu manajemen organisasi dalam pelaksanaan, fungsi perencanaan, koordinasi, pengawasan dan juga sebagai pedoman kerja dalam menjalankan organisasi untuk tujuan yang telah ditetapkan. Perencanaan merupakan salah satu fungsi manajemen dan fungsi ini merupakan salah satu fungsi manajemen dan fungsi ini merupakan dasar pelaksanaan fungsi-fungsi manajemen lainnya. Sebelum organisasi dalam hal ini Direktorat Jenderal Pajak menjalankan strateginya, pimpinan dari organisasi tersebut harus lebih dahulu merumuskan kegiatan-kegiatan apa yang akan dilaksanakan di masa datang dan hasil yang akan dicapai dari strategi tersebut, serta bagaimana melaksanakan strateginya. Anggaran merupakan salah satu cara mengadakan pengawasan dalam organisasi. Pengawasan itu merupakan usaha-usaha yang ditempuh agar rencana yang telah disusun sebelurnnya dapat dicapai. Dengan demikian pengawasan adalah mengevaluasi strategi dan tindakan perbaikan strategi. Aspek pengawasan yaitu dengan membandingkan antara hasil dengan yang dianggarkan, apakah dapat ditemukan efisiensi atau apakah para pegawai pajak telah bekerja dengan baik dalam menjalankan strategi peningkatan penerimaan pendapatan pajak dari sektor UMKM. Tujuan pengawasan itu bukanlah mencari kesalahan akan tetapi mencegah dan nemperbaiki kesalahan.

Fungsi dari sarana dan prasarana dapat berbeda sesuai dengan ruang lingkup dan juga penggunaannya, tetapi mempunyai suatu tujuan yang sama yaitu tujuan untuk mencapai hasil yang di harapkan sesuai dengan rencana. Berikut adalah fungsi utama sarana dan prasarana, yaitu : a) Dapat mempercepat proses pelaksanaan startegi sehingga mampu menghemat waktu, b) meningkatkan produktivitas kerja pegawai pajak, c) hasil kerja pegawai pajak dala menjalankan strategi lebih berkualitas serta terjamin, d) Dapat lebih sederhana atau memudahkan dalam gerak para pegawai pajak, e) membuat ketetapan susunan stabilitas pegawai pajak lebih terjamin, f) menimbulkan rasa kenyamanan bagi pelaksana startegi di lapangan, g) menimbulkan rasa puas pada pegawai pajak yang melaksanakan startegi.

Dalam rangka menjalankan startegi yang baik, dibutuhkan sumber daya manusia pegawai pajak yang berkompetensi . Pegawai pajak merupakan pihak yang beinteraksi langsung dengan wajib pajak. Kualitas layanan pajak sangat tergantung pada persepsi wajib pajak terhadap pelayanan yang diberikan oleh pegawai pajak. Karena itulah sangat penting menentukan dan mengembangkan kompetensi pegawai pajak.

Kompetensi menurut para ahli didefinisikan sebagai suatu kemampuan untuk melaksanakan atau melakukan suatu pekerjaan atau tugas yang dilandasi atas keterampilan dan pengetahuan serta didukung oleh sikap kerja yang dituntut oleh pekerjaan tersebut Kompetensi merupakan landasan dasar karakteristik orang dan mengindikasikan cara berperilaku atau berpikir, menyamakan situasi, dan mendukung untuk periode waktu cukup lama. Strategi dalam meningkakat pelayanan pajak yang berkualitas hampir sulit didapatkan tanpa adanya dukungan dari kompetensi (pengalaman, pengetahuan, skill, dan sikap) dan kuantitas pegawai, kedua hal tersebut akan memberikan dampak yang cukup baik bagi kepuasan nasabah.

Kompetensi merupakan kemampuan untuk melaksanakan atau melakukan suatu pekerjaan atau tugas yang dilandasi atas keterampilan dan pengetahuan serta didukung oleh sikap kerja. Semakin tinggi kompetensi pegawai, maka kesadaran dan kepuasan wajib pajak juga akan 
semakin kuat. Semakin baik pengalaman, penetahuan, keterampilan, dan kuantitas pegawai pajak maka startegi peningkatan penerimaan pajak dari sektor UMKM akan berjalan dengan baik. Wajib pajak akan merasa harapan dan kebutuhannya terpenuhi dengan baik. Dengan demikian kesadaran Wajib pajak dalam membayar pajak dapat ditingkatkan.

Melalui daya dukung yang meliputi anggran dan sarana prasaran serta sumber daya manusia yang meliputi pengalaman, pengetahuan, keterampilan, dan jumlah pegawai diharapkan startegi yang ditetapkan oleh Direktorat jenderal Pajak dapat berjalan dengan baik. Semakin didukung oleh anggaran dan sarana prasaran serta sumber daya manusia yang berpengalaman, berpengetahuan, terampil, dan jumlah pegawai yang memadai maka suatu strategi akan lebih efektif dan efisien dalam mencapai tujuan organisasi, dalam hal ini adalah peningkatan penerimaan sektor pajak UMKM

TABLE 3 | Tabel Limit Supermatriks

\begin{tabular}{|c|c|c|c|c|c|c|c|c|c|}
\hline & \multicolumn{2}{|c|}{ Daya Dukung } & \multicolumn{2}{|l|}{ SDM } & \multirow[b]{2}{*}{$\begin{array}{l}\text { Knowl- } \\
\text { edge }\end{array}$} & \multirow[b]{2}{*}{$\begin{array}{l}\text { Kuanti- } \\
\text { tas }\end{array}$} & \multicolumn{2}{|c|}{ Alternatif Strategi } & \multirow[b]{2}{*}{ S3 } \\
\hline & Anggaran & arpras & $\begin{array}{l}\text { Pengala- } \\
\text { man }\end{array}$ & $\begin{array}{l}\text { Keter- } \\
\text { ampilan }\end{array}$ & & & S1 & S2 & \\
\hline Daya Anggaran & 0.2880 & 0.2880 & 0.2880 & 0.2880 & 0.2880 & 0.2880 & 0.2880 & 0.2880 & 0.2880 \\
\hline Dukunsarpras & 0.1625 & 0.1625 & 0.1625 & 0.1625 & 0.1625 & 0.1625 & 0.1625 & 0.1625 & 0.1625 \\
\hline $\begin{array}{l}\text { Pengala- } \\
\text { man }\end{array}$ & 0.1431 & 0.1431 & 0.1431 & 0.1431 & 0.1431 & 0.1431 & 0.1431 & 0.1431 & 0.1431 \\
\hline $\begin{array}{l}\text { SDM } \text { Keter- } \\
\quad \text { ampilan }\end{array}$ & 0.0722 & 0.0722 & 0.0722 & 0.0722 & 0.0722 & 0.0722 & 0.0722 & 0.0722 & 0.0722 \\
\hline $\begin{array}{l}\text { Knowl- } \\
\text { edge }\end{array}$ & 0.0750 & 0.0750 & 0.0750 & 0.0750 & 0.0750 & 0.0750 & 0.0750 & 0.0750 & 0.0750 \\
\hline Kuantitas & 0.0937 & 0.0937 & 0.0937 & 0.0937 & 0.0937 & 0.0937 & 0.0937 & 0.0937 & 0.0937 \\
\hline S1 & 0.0400 & 0.0400 & 0.0400 & 0.0400 & 0.0400 & 0.0400 & 0.0400 & 0.0400 & 0.0400 \\
\hline Altern & 0.0710 & 0.0710 & 0.0710 & 0.0710 & 0.0710 & 0.0710 & 0.0710 & 0.0710 & 0.0710 \\
\hline S3 & 0.0545 & 0.0545 & 0.0545 & 0.0545 & 0.0545 & 0.0545 & 0.0545 & 0.0545 & 0.0545 \\
\hline
\end{tabular}

Keterangan :

Strategi 1 mempunyai nilai limit 0.0400 serta berada diperingkat ketiga (3)

Strategi 2 mempunyai nilai limit 0.0710 serta berada di peringkat pertama (1)

Strategi 3 mempunyainilai limit 0.0545 sertaberada diperingkat kedua (2)

\section{Prioritas Strategi Peningkatan Penerimaan Pajak Sektor UMKM}

Berdasarkan hasil perangkingan strategi peningkatan penerimaan Pajak sektor UMKM didapatkan hasil bahwa strategi teratas yang mendapatkan nilai tertinggi adalah strategi kedua, yaitu peningkatan pelayanan kepada wajib pajak melalui kemudahan dalam pelaporan pajak, kemudahan pembayan pajak dan kemudahan akses informasi perpajakan.

Jika mengacu pada fakta di lapangan maka kemudahan dalam melaporkan pajak pada sektor UMKM dapat meningkatkan kesadarandan kepatuhan wajib pajak. Hal ini dikarenakan, prosedur pelaporan yang sederhana, dan mudah akan membuat wajib pajak terdorong membayar pajak. Wajib pajak akan terbantu dan mendapatkan kemudahan dalam mengurus pembayaran pajak. Wajib pajak akan mudah dalam menghitung, membayar, dan melaporkan pajak.

Penerapan peraturan yang lebih sederhana, tidak banyak prosedur akan meningkatkan kesadaran dan kepatuhan wajib pajak. Persepsi wajib pajak terhadap kemudahan pelaporan dan pembayaran pajak diharapkan mampu meningkatkan perolehan pajak dari Sektor UMKM.

Kemudahan dalam membayar Pajak bisa diwujudkan antara lain dengan selalu meningkatkan sistem pembayaran secara elektronik, menggabungkan beberapa jenis pajak atau bahkan menghapus jenis pajak yang tidak relevan, dan menyederhanakan proses pelaporan Wajib Pajak.

Kemudahan akses informasi perpajakan. Kini, wajib pajak jika ingin mengurus urusan perpajakan tidak harus datang ke Kantor Pelayanan Pajak (KPP). Mendekatkan diri kepada wajib pajak ini adalah salah satu wujud \#ReformasiPajak dalam bidang layanan, sehingga wajib pajak bisa makin mudah menjangkau layanan perpajakan. Ada 3 cara yang dilakukan DJP untuk mendekatkan diri kepada wajib pajak yakni melalui Mobile Tax Unit seperti Mobil Pajak, Gerai 
Pajak, dan Pojok Pajak, Mall Pelayanan Publik (piloting), dan Kiosk Pajak (piloting). Layanan yang diberikan pun seperti layanan di KPP antara lain pembuatan NPWP, cetak ulang NPWP, pembuatan id billing, penerimaan SPT dan lain sebagainya.

Kemudahan wajib pajak dalam mnegakses informasi perpajakan akan membuat wawasan wajib pajak terbuka. Wajib pajak yang masih belum mendapatkan sosialisasi pajak secara menyeluruh akan mendapatkan kemudahan akses informasi perjapajakan.

Kurangnya informasi perpajakan selama ini telah menyebabkan rendahnya kesadaran masyarakat khususnya pelaku UMKM memiliki kesadaran dan kepatuhan yang rendah dalam membayar pajak. Dengan memberikan kemudahan akses informasi kepada wajib pajak, pengetahuan perpajakan wajib pajak semakin membaik akan mempengaruhi sikap Wajib Pajak dalam memenuhi kewajibannya secara benar.

Kesadaran Wajib Pajak akan meningkat bilamana dalam masyarakat muncul persepsi tentang pajak. Dengan meningkatnya pengetahuan perpajakan masyarakat melalui akses infromasi akan berdampak positif terhadap pemahaman dan kesadaran Wajib Pajak dalam membayar pajak. Akses informasi dibuka dengan dukungan penyuluhan perpajakan secara intensif dan kontinyu.

Melalui strategi peningkatan pelayanan pajak kepada wajib pajak UMKM yaitu dengan memudahkan pelaporan pajak, memudahkan pembayaran pajak, dan memudahkan akses informasi pajak diharapkan mampu meningkatkan kesadaran masyarakat dapam membayar pajak. Pada akhirnya tujuan dari strategi peningkatan penerimaan pajak sektor UMKM melalui peningkatan pelayanan dapat tercapai. Target yang ditetapkan oleh Direktorat Jender

\section{KESIMPULAN}

Berdasarkan metode Analisis Network Proses (ANP) didapatkan prioritas strategi peningkatan penerimaan pada dari sektor UMKM dengan metode Analisis Network Proses (ANP). Rangking pertama yang mendapatkan nilai tertinggi yaitu strategi peningkatan pelayanan pajak kepada wajib pajak UMKM. Pelayanan pajak kepada wajib pajak UMKM ini meliputi kemudahan dalam pelaporan pajak, kemudahan dalam pembayaran pajak, dan kemudahan dalam mengakses informasi pajak.

Penentuan prioritas atau perangkingan strategi peningkatan pelayanan pajak kepada wajib pajak UMKM dalam penelitian ini didasarkan pada kriteria daya dukung dan sumber daya manusia untuk menjalankan startegi. Kriteria daya dukung meliputi sub kriteria anggaran dan sarana prasarana. Kriteria sumber daya manusia meliputi sub kriteria pengalaman, pengetahuan, keterampilan, dan kuantitas pegawai.

Melalui strategi peningkatan pelayanan pajak kepada wajib pajak UMKM diharapkan dapat meningkatkan kesadaran dan kepatuhan wajib pajak sehingga pada akhirnya mampu meningkat perolehan pajak sektor UMKM.

\section{UCAPAN TERIMA KASIH}

Terimakasih kepada KPP Sidoarjo yang memberikan ijin untuk mengambil data informan, dan pihak yang membantu hingga penelitian ini bisa terselesaikan.

\section{REFERENSI}

1. Akinboade, Oludele Akinloye. (2015). Correlates of Tax Compliance of Small and Medium Size Bussiness in Cameroon. Gordon University of Business Science., South Africa.

2. Arikunto, S. (2010). prosedur penelitian : suatu pendekatan praktik. Jakarta: Rineka Cipta.

3. Bramasto, Ari. (2009). Pengaruh Kepatuhan Wajib Pajak dan Kualitas Informasi Akuntansi Keuangan Terhadap Efektivitas Sistem Self Assesment. Jurnal Majalah Unikom Vol. 10, No.2. Hal:179-190. 
4. Fajarwati, Riska Noer, Kertahadi \& Kurniawan, Bondan Catur. (2014). Analisis Peningkatan Kepatuhan Wajib Pajak Sebelum dan Sesudah Penerapan Modernisasi Administrasi Perpajkan (Studi Pada Kantor Pelayanan Pajak Pratama se Malang Raya). Jurnal Mahasiswa Perpajakan Vol. 1, No.2. Hal:1-10

5. Fidel. (2008). Pajak Penghasilan (Pembahasan UU No. 36/2008 tentang Pajak Pengahasilan Dengan Komentar Pasal per Pasal. Jakarta: Caraform Publishing.

6. Fidel. (2008). Pajak Penghasilan (Pembahasan UU No. 36/2008 tentang Pajak Penghasilan Dengan Komentar Pasal Per Pasal). Jakarta: Carofm Publishing.

7. Fuadi, Arabella Oentari \& Mangoting, Yenni. (2013). Pengaruh Kualitas Pelayanan Petugas Pajak, Sanksi Perpajakan dan Biaya Kepatuhan Pajak Terhadap Kepatuhan Wajib Pajak UMKM. Jurnal Tax \& Accounting Review Vol. !, No.1. Hal: 19-27.

8. Hardiningsih, Pancawati. (2011). Faktor-faktor yang Mempengaruhi Kemauan Membayar Pajak The Factors That Influence The Willingness To Pay The Tax. Jurnal Dinamika Keuangan dan Perbankan Vol. 3, No. 1. Hal: 126-142.

9. Harimulyono, Nurrohman. (2008). Pengaruh Administrasi Perpajakan dan Kepatuhan Wajib Pajak Terhadap Penerimaan Pajak Daerah. Jurnal Media Ekonomi Vol. 8, No. 1. Hal:1-16.

10. Herryanto, Marisa \& Toly, Agus Arianto. (2013). Pengaruh Kesadaran Wajib Pajak, Kegiatan Sosialisasi Perpajakan, dan Pemeriksaan Pajak Terhadap Penerimaan Pajak Penghasilan di KPP Pratama Surabaya Sawahan. Jurnal Tax \& Accounting Review Vol. 1, No. 1. Hal:125-135

11. Irawan. Prasetya, 2006. Penelitian Kualitatif \& Kuantitatif untuk Ilmu-Ilmu Sosial, Jakarta: Departemen Ilmu Administrasi FISIP-UI.

12. Jatmiko, Agus Nugroho. (2006). Pengaruh Sikap Wajib Pajak Pada Pelaksanaan Sanksi Denda, Pelayanan Fiskus dan Kesadaran Perpajakan Terhadap Kepatuhan Wajib Pajak (Studi Empiris Terhadap Wajib Pajak Orang Pribadi di Kota Semarang). Tesis. Universitas Diponegoro. Semarang.

13. Jotopurnomo, Cindy \& Mangoting, Yenni. (2013). Pengaruh Kesadaran Wajib Pajak, Kualitas Pelayanan Fiskus, Sanksi Perpajakan, Lingkungan Wajib Pajak Berada Terhadap Kepatuhan Wajib Pajak Orang Pribadi di Surabaya. Jurnal Tax \& Accounting Review Vol. 1, No. 1. Hal:5054.

14. Mardiasmo. (2011). Perpajakan Edisi Revisi 2011. Yogyakarta: CV. Andi Offset.

15. Moleong, Lexy J. (2011). Metodologi Penelitian Kualitatif. Edisi Revisi. Bandung: Remaja Rosdakarya.

Conflict of Interest Statement: The authors declare that the research was conducted in the absence of any commercial or financial relationships that could be construed as a potential conflict of interest.

Copyright (c) 2020 Rahmawati and Nasih. This is an openaccess article distributed under the terms of the Creative Com- mons Attribution License (CC BY). The use, distribution or reproduction in other forums is permitted, provided the original author(s) and the copyright owner(s) are credited and that the original publication in this journal is cited, in accordance with accepted academic practice. No use, distribution or reproduction is permitted which does not comply with these terms. 